\title{
Research on the Evaluation of China's Regional Industrial Green Transformation Development Ability
}

\author{
Xiao-Song REN \\ School of Management Science \& Engineering \\ Shanxi University of Finance \& Economics \\ Taiyuan, China \\ renxiaosong1986@163.com
}

\author{
Tian-Mei SUN \\ School of Management Science \& Engineering \\ Shanxi University of Finance \& Economics \\ Taiyuan, China \\ 18735115258@163.com
}

\begin{abstract}
Through the construction of the evaluation index system of regional industrial green transformation and development ability, the entropy model is used to analyze the industrial green transformation and development ability in $\mathbf{3 0}$ provinces in China in 2014, and it is found that the industrial green transformation ability has obvious regional diversity. The empirical results the empirical results are as follows. Firstly, the transformation of green industrial development capability of Jiangsu province ranks first in China. Secondly, compared with the inland provinces and cities, the eastern coastal provinces and cities have stronger green industrial transformation development capabilities. Thirdly, industrial green transformation development scores are calculated from three aspects, such as environmental protection, resource conservation, and economic benefits. And the indicators related to economic benefits contribute the most to the scores. Finally, on the basis of the empirical analysis, we give policy recommendations from two aspects of changing the development concept and improving the technological innovation ability.
\end{abstract}

Keywords-industrial transformation; green development; entropy model

\section{INTRODUCTION}

Chinese central government China, puts forward the "innovation, harmony, green, open, sharing" five major development concept in national "13th Five-Year" plan, emphasizing green development and industrial transformation. Now, China needs the coordination development transformation from extensive to intensive, and from local to the overall. So, the industrial green transformation development is imminent. Green transformation development involves all sectors of society, as well as all stages of national life, and it plays a big role in sustainable development. And since 2014, China's economic development has entered into a new normal stage, facing the double test of energy saving and emission reduction to cope with climate change and economic development. In this condition, how to achieve the transformation and upgrading of the industrial green development will be top priorities for a national strategy. The development of the industrial economy has shown extensive development for a long time and has an urgent need for transformation and development. Therefore, to evaluate the current situation of industrial green transformation is an important prerequisite for the study of industrial green transformation development.

Study on the industrial transformation and upgrading, both at home and abroad respectively, scholars both at home and abroad have studied the definition, connotation and driving factors of the concept. (1) Research on the enterprise transformation and upgrading began in the 1990s, and scholars gave its concept from the view of the global value chain (GVC), product production and enterprise value level. That is a development process for enterprises from laborintensive to capital or technology-intensive, and from lowvalue products to high value-added products.[1]- [4] Enterprise transformation is a strategic change when the enterprise is facing development problems. The existing research on the definition of enterprise transformation is mainly focused on the industrial transformation, organizational transformation and enterprise re-engineering [5]-[8]. Although the research perspective is slightly different, the definition of transformation still focuses on the changes that organizations or enterprises make in order to change the status quo, solve the crisis, gain competitiveness and cope with environmental change. (2) The existing research on the motivation of transformation and upgrading can be divided into two parts: exogenous motivation and endogenous motivation. Endogenous motivation is based on Resourcebased theory, while exogenous motivation is based on Contingency Theory. The resource-based theory pays attention to the competitive advantage of enterprises, and the key resources and key capabilities possessed by enterprises are the basis of transformation and upgrading, and the key resources include capital accumulation and human resources. To a certain extent, the success or failure of enterprise transformation depends on whether the enterprise has enough capital to invest in technological innovation and enterprise brand image and whether to have professional technical staff and management personnel[9][10]. The key capabilities of an enterprise include the capability of independent innovation [11] and marketing service, which are also important factors for the success of transformation and upgrading. The external motivation based on contingency theory is the external environment and the entrepreneur concept. The external environment includes the stringency of laws, the pressure of stakeholders, changes in the government regulation, and the consumer behavior [12], which the government regulation is conducive to promoting the rapid implementation of the 
transformation and upgrading of enterprises [13]. And the entrepreneurial spirit and corporate culture have different influences on the choice of different upgrading paths [14].

TABLE I. EVALUATION OF TRANSITION DEVELOPMENT AND GREEN DEVELOPMENT

\begin{tabular}{|c|c|c|c|c|}
\hline Author & \begin{tabular}{|c|} 
Research \\
Topic
\end{tabular} & \begin{tabular}{|c|} 
Research \\
Method
\end{tabular} & Index system & Research Review \\
\hline \begin{tabular}{|} 
Cheng \\
Huifang, \\
Tang \\
Huiliang \\
Chen \\
Chao(201 \\
1)[15]
\end{tabular} & $\begin{array}{c}\text { Regional } \\
\text { transform } \\
\text { ation } \\
\text { upgrade }\end{array}$ & $\begin{array}{c}\text { principal } \\
\text { componen } \\
t \text { analysis }\end{array}$ & \begin{tabular}{|c|} 
From economic \\
development, \\
technological \\
innovation \\
capability, \\
industrial \\
upgrading \\
capabilities, \\
international \\
Development \\
capabilities, \\
energy-saving \\
emission \\
reduction \\
capacity of 5 \\
aspects of the \\
construction of \\
indicators system
\end{tabular} & $\begin{array}{l}\text { The establishment of the } \\
\text { index system is mainly } \\
\text { based on the evaluation } \\
\text { of economic transition, } \\
\text { and the index involves } \\
\text { the measurement of } \\
\text { energy saving and } \\
\text { emission reduction } \\
\text { capacity. After empirical } \\
\text { analysis, the data is easy } \\
\text { to obtain, which is of } \\
\text { great significance for the } \\
\text { construction of the index } \\
\text { system of this research }\end{array}$ \\
\hline \begin{tabular}{|c|} 
Wang \\
Yuyan, \\
Wang \\
Ling, \\
Zhan \\
Pianpian( \\
2016)[16]
\end{tabular} & $\begin{array}{c}\text { Industrial } \\
\text { transform } \\
\text { ation and } \\
\text { upgrading }\end{array}$ & $\begin{array}{c}\text { principal } \\
\text { componen } \\
\mathrm{t} \text { analysis }\end{array}$ & \begin{tabular}{|c|} 
From the 4 \\
aspects of \\
economic \\
benefits, \\
technological \\
innovation, \\
structural \\
optimization and \\
green driving, 18 \\
indexes are \\
selected to \\
construct the \\
index system
\end{tabular} & $\begin{array}{l}\text { The research topic is the } \\
\text { industrial transformation } \\
\text { and upgrading. The } \\
\text { index system is based on } \\
\text { the effect of } \\
\text { transformation and } \\
\text { upgrading. The index } \\
\text { data is easy to obtain } \\
\text { and the index system is } \\
\text { relatively reasonable. }\end{array}$ \\
\hline $\begin{array}{c}\text { Zhu } \\
\text { Chunhong } \\
\text {, Ma Tao } \\
(2011) \\
{[17]}\end{array}$ & $\begin{array}{c}\text { Green } \\
\text { industry } \\
\text { developm } \\
\text { ent }\end{array}$ & $\begin{array}{c}\text { factor } \\
\text { analysis }\end{array}$ & \begin{tabular}{|c|}
26 indexes are \\
selected from \\
three standard \\
layers: economic \\
index, ecological \\
environment \\
index and social \\
evaluation index, \\
and the index \\
system is \\
constructed \\
\end{tabular} & $\begin{array}{l}\text { The index system has } \\
\text { strong operability, but } \\
\text { the theme of evaluation } \\
\text { is "green industry" and } \\
\text { "industry green } \\
\text { transformation ability" }\end{array}$ \\
\hline \begin{tabular}{|c|} 
Zhou \\
Ying, \\
Wang \\
Hongzhi, \\
Chi \\
Guotai \\
$(2016)$ \\
{$[18]$}
\end{tabular} & $\begin{array}{c}\text { Green } \\
\text { industry } \\
\text { evaluatio } \\
n\end{array}$ & $\begin{array}{c}\text { R cluster } \\
\text { factor } \\
\text { analysis } \\
\text { method }\end{array}$ & \begin{tabular}{|c|} 
From green \\
production, green \\
consumption and \\
green \\
environment \\
three standard \\
layers, select 26 \\
indicators, build \\
index system
\end{tabular} & $\begin{array}{c}\text { The classification of } \\
\text { refining indexes lacks } \\
\text { the logic of careful } \\
\text { evaluation, and the } \\
\text { theme of evaluation is } \\
\text { different from that of } \\
\text { industrial green } \\
\text { transformation. Green } \\
\text { consumption does not } \\
\text { belong to the evaluation } \\
\text { field of industrial green } \\
\text { transformation ability }\end{array}$ \\
\hline
\end{tabular}

The domestic and foreign scholars on the transformation and upgrading of the abundant research achievements, mainly focus on the transformation and upgrading of enterprises, and few studies on the green transformation of industries. The main research object is the issues of developed countries, less concerned about how to upgrade and promote green development in developing countries. Most of the research methods are descriptive and normative analysis. Some scholars define the green economy as a new mode of economic development. It is not only characterized by the green industry but also includes all kinds of economic forms, such as circular economy, resource conservation, ecological environment protection and low-carbon economy. Although China is extremely rich in resources, the per capital resource has a very low amount of resources. The current environmental problems have seriously hindered the development of social economy, so green development has become an important strategy which should be taken by China's government [19]. Different from the general sustainable development, green economy pays more attention to the coordination of economy, environment, and resources, which advocates considering the relationship between the three as a whole. With the green economy as the main body, many scholars have put forward more "green" concepts, such as green welfare, green planning, green wealth, green finance and green transformation and so on. Green economy means human activities with both environmental and economic benefits, and emphasizes the two meanings of "green economy", "economic development should be environmentally friendly", and "environmental protection needs economic savings". Scholars' research has provided theoretical and practical guidance for China's industrial transformation and upgrading and green economic development, but most of them only take one of the two as the research topic. Through the combination of Chinese practice and advanced theories abroad, scholars have conducted case studies and empirical studies, but they have not been based on practical problems solved by Chinese situations. On the green transformation of industrial upgrading evaluation research has practical guidance, this paper takes the regional industrial green transformation capability as the research subject to construct the index system and empirical research, through the research of green transformation Chinese regional industrial upgrading ability, in order to seek to enhance green industrial development capability.

\section{RESEARCH FRAMEWORK}

The present study evaluation research in academic circles mainly focus on regional economic transformation ability and the development of green industry (see Table I ), compared the ability of regional economic transition, green transformation and development pay more attention to environmental protection and resource conservation, green transformation capability evaluation of industrial emphasizes the penetration ability of technology and the concept of green development in industrial enterprises transition. Different from the evaluation research of green industry development, the development of industrial green transformation emphasizes the level of integration between transformation and green development. The main research subject of industrial green transformation capability is industrial transformation, and the research perspective is the greening 
of industrial transformation. In contrast, green industry is a concept formed by the extension of environmental protection. Its theme is based on the green environment system, and the green industry is a whole concept. From the connotation and extension of academic research, the relationship between them is that they all pay attention to the integration of green development and industrial development, but each has its own focus in scope.In the evaluation method and index system construction, centering on the integration of green development and industrial development, the index system of both can learn from each other within a certain range.

The evaluation system constructed in this paper is based on the construction of Cheng Huifang, Tang Huiliang, Chen Chao [15], Wang Yuyan, Wang Ling, Zhan Pianpian [16], Zhu Chunhong, Ma Tao [17], considering the characteristics of the regional industrial green transformation, the index system formed with industrial green transformation is expected to achieve the effect, that is, resource conservation, environmental friendliness and economic efficiency improvement as the first level indicators. Therefore, this paper sets up an index system from three aspects of environmental protection, resource conservation, and economic benefits, and uses entropy method to quantitatively evaluate the industrial green transformation capability in each province. Based on the idea of the above evaluation, through the analysis of the related literature at home and abroad, combined with the index of data availability and operability of the evaluation scheme, this paper determines the evaluation system of the provincial industry consists of 19 specific indicators of green transformation capability (Table II).

\section{DATA AND METHODS}

\section{A. Data Sources}

The selected 19 indicators regional industrial R\&D expenditure, gross industrial production, education, population, industrial fixed assets investment, high-tech industrial output value, industrial energy consumption and the industrial power consumption of 30 China's provinces in 2014. Due to the limitation of collecting data, the chosen provinces, cities, and municipalities do not include Tibet, Macao, Taiwan, and Hong Kong. And the data are derived from Chinese Industry Statistical Yearbook, Chinese Statistical Yearbook, Chinese Energy Statistics Yearbook, Chinese Industry Statistical Yearbook, Chinese Education Statistical Yearbook, and China Environmental Statistics Yearbook.

\section{B. Entropy Model}

According to the basic theory of information theory, entropy value is a measure of the degree of uncertainty of the information system. If a system has a high degree of certainty, the information entropy is small. On the contrary, if a system has a high degree of uncertainty, then the information entropy is large [20].
TABLE II. INDUSTRIAL GREEN TRANSITION CAPABILITY INDEX SYSTEM

\begin{tabular}{|c|c|c|c|}
\hline \begin{tabular}{|c|}
$\begin{array}{c}\text { measurement } \\
\text { goals }\end{array}$ \\
\end{tabular} & \begin{tabular}{|c|} 
first level \\
indicators \\
\end{tabular} & specific indicators & $\begin{array}{c}\text { pointer } \\
\text { type }\end{array}$ \\
\hline \multirow{3}{*}{$\begin{array}{c}\text { Evaluation of } \\
\text { green } \\
\text { transformation } \\
\text { capability of } \\
\text { regional } \\
\text { industry }\end{array}$} & $\begin{array}{l}\text { environme } \\
\text { ntal } \\
\text { protection( } \\
\text { X1) }\end{array}$ & $\begin{array}{c}\mathrm{CO}_{2} \text { emission per unit industrial } \\
\text { output value(X11) } \\
\text { Emissions per unit of industrial } \\
\text { output value(X12) } \\
\text { Output of waste water per unit } \\
\text { industrial output value(X13) } \\
\text { Emissions of solid waste per unit of } \\
\text { industrial output value(X14) } \\
\text { Pollution investment accounted for } \\
\text { GDP(X15) }\end{array}$ & $\begin{array}{l}\text { Negative } \\
\text { Negative } \\
\text { Negative } \\
\text { Negative } \\
\text { Positive }\end{array}$ \\
\hline & $\begin{array}{c}\text { resource } \\
\text { conservatio } \\
n(X 2)\end{array}$ & $\begin{array}{l}\text { Unit industrial added value water } \\
\text { consumption(X21) } \\
\text { Comprehensive utilization rate of } \\
\text { industrial solid waste(X22) } \\
\text { Energy consumption per unit } \\
\text { industrial output value(X23) } \\
\text { Proportion of coal to energy } \\
\text { consumption(X24) } \\
\text { Drop speed unit of industrial output } \\
\text { power consumption(X25) }\end{array}$ & $\begin{array}{l}\text { Negative } \\
\text { Positive } \\
\text { Negative } \\
\text { Negative } \\
\text { Positive }\end{array}$ \\
\hline & $\begin{array}{c}\text { economic } \\
\text { benefits }(X \\
3)\end{array}$ & $\begin{array}{c}\text { asset-liability ratio(X31) } \\
\text { Industry cost margins(X32) } \\
\text { the proportion of industrial R\&D } \\
\text { expenditure to the proportion of } \\
\text { GDP(X33) } \\
\text { The proportion of college } \\
\text { diploma(X34) } \\
\text { Industrial fixed asset investment } \\
\text { growth(X35) } \\
\text { Number of patent licenses(X36) } \\
\text { Per capital GDP(X37) } \\
\text { urbanization rate(X38) } \\
\text { Growth rate of output value of } \\
\text { high-tech industry(X39) }\end{array}$ & $\begin{array}{l}\text { Positive } \\
\text { Negative } \\
\text { Positive } \\
\text { Positive } \\
\text { Positive } \\
\text { Positive } \\
\text { Positive } \\
\text { Positive } \\
\text { Positive }\end{array}$ \\
\hline
\end{tabular}

According to the information content of the indicators, in order to objectively determine the index weight, we use entropy method to evaluate the ability of the green transformation of regional industrial development. The green industrial transformation and upgrading capacity evaluation is a multi-attribute decision-making problem, using entropy method to determine the index weight according to the information content of each index in the evaluation process more objective. Follow the following steps:

1) Standardized processing of raw data

As the meaning and measurement units of each index in the index system are different, so all indices need nondimensional processing. And positive indexes and negative indexes have different standardized.

The positive indicators are processed with the following method:

$$
x_{i j}^{\prime}=\frac{x_{i j}-\min x_{i j}}{\max x_{i j}-\min x_{i j}} \quad\left(0 \leq x_{i j}^{\prime} \leq 1\right)
$$

Also, the negative indicators are treated in the following way: 


$$
x_{i j}^{\prime}=\frac{\max x_{i j}-x_{i j}}{\max x_{i j}-\min x_{i j}} \quad\left(0 \leq x_{i j}^{\prime} \leq 1\right)
$$

Among them, the maximum value and the minimum value are both from every index in the data table. And the original data are dimensionless processed according to Equations 3.1 and 3.2.

2) Calculate entropy value, the coefficient of difference and weight

Firstly, the proportion of the index value of each evaluation unit under each index is determined, and the formula is as follows:

$$
p_{i j}=\frac{x_{i j}^{\prime}}{\sum_{i=1}^{n} x_{i j}^{\prime}}
$$

Then calculate the entropy of each index:

$$
e_{j}=-k \sum_{i=1}^{n} p_{i j} \ln p_{i j}
$$

$k=1 / \ln n$

The coefficient of difference:

$$
d_{j}=1-e_{j}
$$

Calculate the weight according to the coefficient of difference:

$$
a_{j}=\frac{d_{j}}{\sum_{i=1}^{m} d_{j}}
$$

3) Comprehensive evaluation of the ability of industrial green transformation

According to the entropy value, the difference coefficient, and the weight, the comprehensive evaluation value are calculated:

$$
v i=\sum_{j=1}^{n} a_{j} p_{i j}
$$

\section{RESULT ANALYSIS AND DISCUSSIONS}

\section{A. Overall Evaluation And Comparison of Regional Green Transformation Development Ability}

According to the formula 3.3-3.6, the entropy value, the difference coefficient and the weight of the industrial green transformation and upgrading ability evaluation indices can be calculated, as shown in Table III. The empirical results show that the top five indicators which have big weights in the evaluation system of regional industrial green transformation development ability are Number of patent
licenses(X36), Pollution investment accounted for GDP(X15), the proportion of college diploma(X34), per capital GDP and $R \& D$ expenditure accounted for GDP(X33). Except that pollution investment accounted for GDP belongs to the environmental protection index, the remaining four indicators belong to economic indicators. Especially, the number of patent licenses, the proportion of college diploma, and the proportion of industrial R\&D expenditure are often used as proxies for the innovation ability of enterprise technology, and the level of scientific and technological innovation ability will have a certain impact on the economic benefits.

The comprehensive score of regional industry in 2014 the green transformation capability, in the first row of the Jiangsu province is the comprehensive evaluation value of 0.6474 , including environmental protection, resource conservation, and economic value is $0.0567,0.1506,0.4401$, of which the maximum economic benefits, compared with the other 29 provinces is also ranked in the first place; resource conservation. Jiangsu province ranked third in all regions of the country; and the environmental protection value of 23 ranked 30 in the province's environmental protection work, so there is room for development. The next is Tianjin city and Guangdong Province, the comprehensive evaluation values were 0.6261 and 0.6074 , in three two level indexes in the industrial city of Tianjin resource conservation in the first place in 30 provinces, the resource conservation index value is 0.0583 , and in Guangdong Province, the industrial economic benefits except Jiangsu province is the highest, its value is 0.4267 .

Compared with other provinces, Yunnan, Jiangxi, and Guizhou, these three provinces or cities have an obvious weakness in the industrial green transformation development ability, which comprehensive scores of green transformation development ability are $0.2302,0.2338$, and 0.2507 respectively. Specific to the three aspects of environmental protection, resource conservation, and economic performance, environmental protection score of Yunnan Province is 0.0471, ranking at the top ten. Meanwhile, the environmental protection score of Guizhou province is 0.0460 , ranking at 20 in the whole country. It is worth noting that industry environmental protection of Jiangxi province still needs to be improved. And resource conservation and economic efficiency indicators of the three provinces level are not very different, and almost rank at lower levels in the whole country, so the industrial resource conservation and economic development ability need to be improved.

\section{B. Sub Item Evaluation And Comparison of Regional Green Transformation Development Ability}

Taking data into formula 3.7, we can get the first-grade evaluation index and the comprehensive evaluation score of the green transformation development ability of the 30 provinces in China. The result is shown in Table IV. In order to further understand the changes and development trend of the elements of the green transition development capacity of the whole country, this paper evaluates and analyzes three indicators such as environmental protection, resource conservation, and economic benefits. 
TABLE III. THE ENTROPY, DIFFERENCE COEFFICIENT, AND WEIGHT

\begin{tabular}{|c|c|c|c|}
\hline index & entropy & $\begin{array}{c}\text { Coefficient } \\
\text { of } \\
\text { difference }\end{array}$ & weight \\
\hline $\begin{array}{c}\mathrm{CO}_{2} \text { emission per unit industrial output } \\
\text { value(X11) }\end{array}$ & 0.9899 & 0.0101 & 0.0105 \\
\hline $\begin{array}{c}\text { Emissions per unit of industrial output } \\
\text { value(X12) }\end{array}$ & 0.9799 & 0.0201 & 0.0209 \\
\hline $\begin{array}{c}\text { Output of waste water per unit industrial } \\
\text { output value(X13) }\end{array}$ & 0.9889 & 0.0111 & 0.0115 \\
\hline $\begin{array}{l}\text { Emissions of solid waste per unit of } \\
\text { industrial output value(X14) }\end{array}$ & 0.9832 & 0.0168 & 0.0174 \\
\hline $\begin{array}{l}\text { Pollution investment accounted for } \\
\text { GDP(X15) }\end{array}$ & 0.8537 & 0.1463 & 0.1521 \\
\hline $\begin{array}{l}\text { Unit industrial added value water } \\
\text { consumption(X21) }\end{array}$ & 0.9694 & 0.0306 & 0.0318 \\
\hline $\begin{array}{c}\text { Comprehensive utilization rate of industrial } \\
\text { solid waste(X22) }\end{array}$ & 0.9485 & 0.0515 & 0.0535 \\
\hline $\begin{array}{c}\text { Energy consumption per unit industrial } \\
\text { output value(X23) }\end{array}$ & 0.9783 & 0.0217 & 0.0225 \\
\hline $\begin{array}{l}\text { Proportion of coal to energy } \\
\text { consumption(X24) }\end{array}$ & 0.9367 & 0.0633 & 0.0658 \\
\hline \begin{tabular}{|c|}
$\begin{array}{c}\text { Drop speed unit of industrial output power } \\
\text { consumption(X25) }\end{array}$ \\
\end{tabular} & 0.9824 & 0.0176 & 0.0183 \\
\hline asset-liability ratio(X31) & 0.9569 & 0.0431 & 0.0448 \\
\hline Industry cost margins(X32) & 0.9788 & 0.0212 & 0.0220 \\
\hline R\&D expenditure accounted for $\operatorname{GDP}(\mathrm{X} 33)$ & 0.9016 & 0.0984 & 0.1023 \\
\hline The proportion of college diploma(X34) & 0.8779 & 0.1221 & 0.1270 \\
\hline $\begin{array}{l}\text { Industrial fixed asset investment } \\
\text { growth(X35) } \\
\end{array}$ & 0.9810 & 0.0190 & 0.0197 \\
\hline Number of patent licenses(X36) & 0.7840 & 0.2160 & 0.2246 \\
\hline Per capital GDP(X37) & 0.8811 & 0.1189 & 0.1236 \\
\hline urbanization rate(X38) & 0.9220 & 0.0780 & 0.0811 \\
\hline $\begin{array}{l}\text { Growth rate of output value of high-tech } \\
\text { industry(X39) }\end{array}$ & 0.9821 & 0.0179 & 0.0186 \\
\hline
\end{tabular}

Environmental protection scores across the country have little difference. The specific indexes X11-X15 weights are $0.0105,0.0209,0.0115,0.0174$ and 0.1521 . We can see that Pollution investment accounted for GDP(X15) is the largest in the environmental protection index. Ningxia's pollution control investment accounted for the largest proportion of industrial output value of $0.178 \%$, and its investment in pollution control was 2 billion 729 million 670 thousand yuan, while Shandong province is the largest investment in pollution control nationwide, and the investment in pollution control is 14 billion 164 million 642 thousand and 100 yuan. Industrial emissions of greenhouse gases, industrial waste emissions largest provinces are Xinjiang, Ningxia, Qinghai, Hainan, and the lowest emissions are Beijing, Beijing, Shanghai, and Heilongjiang. Compared with Xinjiang, Beijing, Shanghai, and Heilongjiang, with energy-saving emission reduction policies and a good atmosphere, agglomeration, technical personnel and the funds gathered in Beijing and other places, resulting in reducing emissions is relatively good.
TABLE IV. 2014 THE FIRST-GRADE EVALUATION INDEX OF GREEN TRANSFORMATION CAPABILITY OF CHINA'S PROVINCIAL INDUSTRIAL SECTOR

\begin{tabular}{|c|c|c|c|c|c|}
\hline area & $\begin{array}{c}\text { environm } \\
\text { ental } \\
\text { protection }\end{array}$ & $\begin{array}{c}\text { resource } \\
\text { onservati }\end{array}$ & $\begin{array}{c}\text { economic } \\
\text { benefits }\end{array}$ & $\begin{array}{c}\text { integrated } \\
\text { assessment } \\
\text { value }\end{array}$ & ranking \\
\hline Beijing & 0.0563 & 0.1494 & 0.3905 & 0.5962 & 4 \\
\hline Tianjin & 0.0583 & 0.1612 & 0.4066 & 0.6261 & 2 \\
\hline Hebei & 0.0516 & 0.0884 & 0.2187 & 0.3587 & 16 \\
\hline Shanxi & 0.0472 & 0.0822 & 0.2153 & 0.3447 & 18 \\
\hline Nei Mongol & 0.0405 & 0.1052 & 0.2928 & 0.4385 & 8 \\
\hline Liaoning & 0.0527 & 0.0917 & 0.2500 & 0.3945 & 13 \\
\hline Jilin & 0.0542 & 0.0735 & 0.1426 & 0.2703 & 27 \\
\hline Heilongjiang & 0.0595 & 0.1090 & 0.2314 & 0.3998 & 12 \\
\hline Shanghai & 0.0593 & 0.1485 & 0.3822 & 0.5900 & 5 \\
\hline Jiangsu & 0.0567 & 0.1506 & 0.4401 & 0.6474 & 1 \\
\hline Zhejiang & 0.0578 & 0.1337 & 0.3774 & 0.5690 & 6 \\
\hline Anhui & 0.0473 & 0.0890 & 0.2567 & 0.3930 & 14 \\
\hline Fujian & 0.0552 & 0.1262 & 0.2325 & 0.4139 & 9 \\
\hline Jiangxi & 0.0460 & 0.0672 & 0.1205 & 0.2338 & 29 \\
\hline Shandong & 0.0577 & 0.1145 & 0.3229 & 0.4950 & 7 \\
\hline Henan & 0.0533 & 0.1563 & 0.1594 & 0.3691 & 15 \\
\hline Hubei & 0.0537 & 0.0838 & 0.2197 & 0.3572 & 17 \\
\hline Hunan & 0.0497 & 0.0736 & 0.1894 & 0.3127 & 21 \\
\hline Guangdong & 0.0561 & 0.1245 & 0.4267 & 0.6074 & 3 \\
\hline Guangxi & 0.0435 & 0.0738 & 0.1964 & 0.3137 & 20 \\
\hline Hainan & 0.0348 & 0.1184 & 0.1519 & 0.3051 & 23 \\
\hline Chongqing & 0.0505 & 0.1334 & 0.2201 & 0.4040 & 11 \\
\hline Sichuan & 0.0505 & 0.1027 & 0.1822 & 0.3354 & 19 \\
\hline Guizhou & 0.0351 & 0.0807 & 0.1350 & 0.2507 & 28 \\
\hline Yunnan & 0.0471 & 0.0623 & 0.1208 & 0.2302 & 30 \\
\hline Shaanxi & 0.0489 & 0.0903 & 0.1473 & 0.2865 & 25 \\
\hline Gansu & 0.0477 & 0.0794 & 0.1705 & 0.2976 & 24 \\
\hline Qinghai & 0.0277 & 0.1160 & 0.1662 & 0.3099 & 22 \\
\hline Ningxia & 0.0258 & 0.0835 & 0.2958 & 0.4051 & 10 \\
\hline Xinjiang & 0.0327 & 0.0956 & 0.1535 & 0.2818 & 26 \\
\hline
\end{tabular}

Tianjin, the largest resource saving score, had a difference of 0.01 compared with Yunnan, the least resource conserving score. The index of water consumption per unit of industrial added value, solid waste utilization rate, unit energy consumption of industrial output, the weight drop speed of the coal consumption structure and industrial output unit power consumption was $0.0318,0.0535,0.0225,0.0658,0.0183$. In 2014, the maximum and minimum X21-X25 index provinces 
are Shanghai and Heilongjiang, Tianjin and Liaoning, Ningxia and Beijing, Jilin and Hainan, Shanghai and Xinjiang.The provinces and cities in which the water consumption per unit of industrial added value is negative are Shanxi, Inner Mongolia, Heilongjiang, Henan, Hainan, Chongqing, and Qinghai. In 2014, the industrial water consumption of units in these provinces was somewhat reduced. The comprehensive utilization rate of industrial solid waste in Tianjin and Liaoning was $99 \%$ and $37 \%$ respectively, and unit of industrial energy consumption of more than 1 provinces: Hebei, Shanxi, Hainan, Yunnan, Gansu, Qinghai, Ningxia, and Xinjiang. Most of these provinces are large provinces of the energy industry and consume more energy. Coal consumption was also used to measure the energy consumption structure, the various provinces and cities nationwide coal consumption accounted for $0.18-0.55$. In the 30 provinces and cities, $1 / 3$ provinces and cities accounted for about 0.2 of coal consumption, more than 0.5 of the provinces are Jilin, Anhui, Hubei, and Hunan. The industrial use of electricity of various provinces and cities vary greatly, Shanghai industrial added value of unit electricity consumption rate of 11 , Xinjiang electricity consumption rate is -11 . The decrease in power consumption is negative, that is, the electricity consumption per unit of industrial added value increases, and the rate of decline in Inner Mongolia is also negative.

Jiangsu, Guangdong, Tianjin, Beijing, Shanghai's economic efficiency score value ranked in the top five, are $0.4354,0.4249,0.3945,0.3846$ and 0.374 respectively. On the contrary, Jiangxi, Guizhou, Xinjiang, Hainan and Yunnan's economic benefit score value at the end in the 30 provinces, and respectively are 0.1159, 0.1074, 0.1030, 0.0960 and 0.0911 . The weight of economic benefits of specific indicators X31-X39 were 0.0448, 0.0220, 0.1023, $0.1270,0.0197,0.2246,0.1236,0.0811,0.0186$. The indices which have the weight of more than 0.1 indicators are as follows: R\&D expenditure accounted for $\operatorname{GDP}(X 33)$, the proportion of college diploma(X34), number of patent licenses(X36) and per capital GDP(X37). Qinghai's R\&D expenditure accounted for GDP is only $0.962 \%$, while Beijing is $6.232 \%$, Shanghai is $6.101 \%$, and Jiangsu is $5.105 \%$. In other areas, R\&D expenditure accounted for GDP is mostly between $1 \%-2.5 \%$, Beijing, Shanghai, and Jiangsu, as a result of good innovation and entrepreneurship policies and atmosphere, attract the talents of the country and the influx of funds, resulting in relatively inadequate resources in other areas.

\section{CONCLUSIONS AND POLICY RECOMMENDATIONS}

Based on the evaluation index system of regional industrial green transformation and development ability, this study attempts to use the entropy model to calculate the industrial green transformation and development ability of China's 30 provinces in 2014. According to the above empirical analysis, we find that there exist significant regional differences and unbalanced status in the green transition development ability among the 30 provinces and cities in China. We further draw interesting and important finding that there are seven eastern coastal provinces and cities ranking at the top ten which get high valuation scores of regional industrial green transformation and development ability. In fact, these high developed provinces have not formed enough radiation to the surrounding areas. On the contrary, human resource, capital investment, and technology inputs are all absorbed to these eastern coastal provinces in all kinds of different way, which leads to the lack of resources inputs and development power for inland provinces and cities to improve the ability of green transformation. From the above analysis, this study derives two policy recommendations as follows, in order to break regional imbalances and achieve coordinated development of green transformation.

\section{A. Change the notion of development, to break the pursuit of high economic growth}

Industrial green transformation and development are not a simple development of environmental protection industry or a new energy-saving industry, but to carry out in-depth transformation and all-around changes from the concept to the production model. And these multi-angle changes start from technology, capital investment, physical forces, personal ideas, and the standard process. Therefore, to speed up the development of industrial green transformation is a profound change in China's industrial development. Based on the notion of green development, this study suggests that we should establish a new green national economic accounting system and green evaluation system, which include economic growth, social development, and environmental protection together. Governments should improve management role and take "green index" as the important evaluation standard, to improve the weight of green index in a comprehensive assessment of performance evaluation, and carry out the regulation by the level target and transformation development evaluation system.

\section{B. Technological Innovation Capability is an Important Way to Foster the Ability of Regional Industrial Green Transformation Development}

The role of technological factors in economic development is to ease the contradiction between economic development and insufficient resources, so as to realize the coordination between economic development, environmental protection, and population growth. The indicators of economic efficiency include R\&D expenditure, the number of patent license and so on, which are used as input or output indicators of technological innovation. From the result of the indices evaluation, some provinces, such as Qinghai and Hainan, are still large short boards in technological innovation. Although Qinghai has certain advantages in the resource saving score, the future of Qinghai will still need comprehensive development in strengthening the green transformation of the industry and strives to narrow the gap with the eastern coastal areas in the development of industrial green transformation. Similarly, Hainan also needs to upgrade its technological level, and develop the green industry to optimize the industrial structure. 


\section{ACKNOWLEDGMENT}

The authors gratefully acknowledge the financial support from the China Scholarship Council (CSC) under grant no.201508140081, Shanxi Province Higher School Philosophy and Social Science Research Project under grant no. 2014235, and Shanxi Provincial Social Science Association Key Project under grant no. SSKLZDKT2016064.

\section{REFERENCES}

[1] Gereffi G, "International trade and industrial upgrading in the apparel commodity chain", Journal of International Economics, vol. 48, June 1999, pp. 37-70, doi: org/10.1016/S0022-1996(98)00075-0

[2] Poon S C, "Beyond the global production networks: a case of further upgrading of Taiwan's information technology industry", International Journal of Technology \& Globalisation, vol. 1, Jan. 2004, pp.130-144, doi: 10.1504/IJTG.2004.004555

[3] Kaplinsky R and Morris M, "A handbook for value chain research", International Development Research Centre [http://www.ids.ac.uk/ids/ global/pdfs/vchnov01.pdf] Kimani, P.M, 2012.

[4] Humphrey J and Schmitz H, "Chain governance and upgrading: Taking stock", Chapters, Jan. 2004, doi $10.4337 / 9781843769743.00020$

[5] Porter M E, "Towards a dynamic theory of strategy", Strategic Management Journal, vol. S2, Dec. 1991, pp: 95-117, doi: 10.1002/smj. 4250121008

[6] Wang deli, Zhang mier, Zhou min, "Review on enterprise technological capability study during industry conversion_Referring the reforging route of technological capability", Journal of Management Sciences in China, Vol. 9, Jun. 2006, pp. 74-80.

[7] Blumenthal B and Haspeslagh P, "Toward a definition of corporate transformation", Jan. 1994, pp. 101-106,

[8] Lin J. "Enlightenment of International Experience in the "Green Economy' Transformation for Developing Countries", Innovative Management in Information and Production. Springer New York, 2014, pp. 171-179.

[9] Forbes $\mathrm{N}$ and Wield D, "From Followers to leaders: managing technology and innovation in newly industrialized countries", Long Range Planning, vol. 37, Jun. 2004, pp. 371-372.

[10] Wang Yiming and Wang Jun, "Consideration on promoting the corporation capability of independent innovation, China Soft Science", vol.7, 2005, pp. 10-14.

[11] Liu Zhi Biao, "The path and the brand strategy of Chinese manufacturing industry upgrading under the background of Globalization", Research on Financial and Economic Issues, vol.5, 2005, pp. 25-31, doi:10.3969/j.issn.1000-176X.2005.05.005

[12] Bansal P and Roth K, "Why companies go green: A model of ecological responsiveness", Academy of Management Journal, vol. 43, April 2000, pp. 717-736, doi: 10.2307/1556363

[13] Joshua S. Gans and Scott Stern, "The product market and the market for "ideas": commercialization strategies for technology entrepreneurs", Research Policy, vol. 32, Feb.2003, pp. 333-350, doi: $10.2139 / \mathrm{ssrn} .317219$.

[14] Silajd I, Kurtagi S M, Vuijak B, "Green entrepreneurship in transition economies: a case study of Bosnia and Herzegovina", Journal of Cleaner Production, vol. 88, Feb. 2015, pp. 376-384, doi: 10.1016/j.jclepro. 2014.07.004

[15] Cheng Huifang, Tang Huiliang, Chen Chao, "Research on comprehensive evaluation of regional economic transformation and upgrading under open conditions -- Analysis of evaluation index system for transformation and upgrading of 31 provinces and cities in China", Management World,vol. 8, 2011, pp. 173-174.

[16] Wang Yuyan, Wang Ling, Zhan Pianpian, "Evaluation Studies on the Effect of Industrial Transformation and Upgrading in China", Journal of Industrial Technological Economics, vol.7, 2016, pp. 130-138, doi: 10. 3969 /j. Issn. 1004-910X. 2016. 07. 016

[17] Zhu Chunhong and Ma Tao, "Research on the effect evaluation of regional green industry development", Research on economics and management, vol.3, 2011, pp. 64-70, doi: 10. 13502/ j.Cnki. Issn10007636. 2011. 03.008

[18] Zhou Ying, Wang Hongzhi, Chi Guitar, "Constructional and application of green industry evaluation indicator system based on factor analysis", Systems Engineering Theory Methodology Application, vol. 25, Feb. 2016, 25, pp. 338-352.

[19] Hu Angang, "Global climate change and China's green development", Chinese Journal of Population Resources and Environment, vol. 9, May. 2011, pp.9-15, doi: 10.1080/10042857.2011.10685044

[20] Wei ping and Yang Minyan, "organizational complexity and internal capital markets efficiency in financial conglomerates: evidence in China", Chinese Journal of Management Science, vol. 6, 2017, pp.1121, doi: 10. 16381/j.cnki.issn1003-207x.2017.06.002 